\title{
An Unlikely Symbiosis: Science and Law
}

\author{
Evan Miller* \\ Department of Humanities and Social Sciences, Southern Utah University, Cedar City, UT \\ https:/ / doi.org/10.33697/ ajur.2020.018 \\ Student:evanmillermiller@suumail.net* \\ Mentor: erickirby@suu.edu*
}

\begin{abstract}
Science has historically held a position of high regard in society. Science is intimately connected to law. These disciplines meet in the courtroom. Due to the nature of civil and criminal disputes in the United States, litigators retain expert witnesses to explicate nuanced subjects, including science. Unfortunately, the common law system has not always favored sound science. This paper examines how science and law can work in concert to benefit all people. Some feel that scientists should simply educate courtrooms, but further scrutiny questions the feasibility of this approach. Understanding the sociology of scientific knowledge elucidates this debate and is applied to the forensic sciences. Science and law have the capacity to improve the human condition and increase equity among all people.
\end{abstract}

\section{KEYWORDS}

Science Communication; Expert Witnesses; Science; Public Perception; Law; Misinformation

\section{INTRODUCTION}

Scientific discovery assists in policy formation and societal advancement, as well as re-evaluating current claims regarding safety and well-being. ${ }^{1}$ Societies encounter complex issues frequently, and the scientific method is an efficacious way to solve the problems people encounter. Due to the fact-finding nature of science, it carries a significant power to improve the human condition for the better. ${ }^{1}$

However, science does not exist in vacuum. Science is created and amended within the confines of human society, often intersecting with the law humans have created for themselves. Law and science cannot live independently. Science and law meet at an interesting crossroads: the courts. The individuals who litigate disputes in the courtroom may not understand the delicate, scientific nuances of every subject they litigate. Conversely, scientists may not be properly equipped to disseminate their findings in such a unique setting. This paper is written as a guide for maximizing the use of science in the courtroom to achieve equitable outcomes.

\section{Part I: Literature Review}

Scientific courtroom disputes are commonplace. A simple search of personal injury dockets in 2019 reveals that attorneys filed more than 300,000 claims in the United States and its territories. Not all of these cases will go to trial, nor will all require scientific experts, but some cases will require expert testimony in open court. For instance, cases regarding defective ear plugs and vaping will require scientific knowledge to guide judges and juries in their decision-making process. The wide variety of cases supersedes the readily available knowledge of courtroom fact finders. For this reason, expert witnesses are allowed in the courtroom, and allowed to be compensated for their testimony, a practice that is typically forbidden in regular courtroom operations. ${ }^{2,3}$ Expert witnesses have the potential to assist judges and juries in reaching sound conclusions.

The United States relies on the common law system to resolve formal disagreements. This system of dispute resolution rests on the principle of stare decisis, a Latin phrase known commonly as "let the decision stand." This means that when judges craft opinions, they look to the previously written body of law on the subject, whether it involves compensation in asbestos cases, or medical malpractice, to name two examples. This creates a body of rule that guides future judges and attorneys. Precedent forms predictions of success at trial. Attorneys can inform clients of the best route to recoup damages or seek relief from adverse legal claims.

Misinformed science can become enshrined in precedent. Judges have previously relied on dubious evidence to convict innocent people. ${ }^{4}$ Any scientist who enters the courtroom must approach their testimony with the understanding that flawed science may have prevailed in the past, and correcting that science requires careful explanation. The courts may not defer to new advances in science immediately. The phenomenon of judicial reticence to acquiesce to current science is illustrated by the citation of one faulty statistic regarding sex offender recidivism in a United States Supreme Court opinion. Supreme Court Justice Anthony 
Kennedy cited a statistic that an estimated $80 \%$ of untreated sex-offenders re-offend. This statistic was then parroted throughout lower courts, negatively affecting sentencing outcomes for convicted individuals. ${ }^{5}$ When this statistic was tracked back to its origin, no acceptable academic proof was provided to support it.

Scientific inquiry is a process that is not intuitive to those not involved with it on a daily basis.6, 7 Science uses an argumentative, skeptical approach to discover information. Scientists who want to publish and disseminate their work present the data in the peer review process, where their peers scrutinize and question the results to ensure they are accurate. This process of peer review is healthy and typically creates constructive dialog. However, peer review can lead to disagreements as to the exact nature of stated conclusions, and these disagreements, while mostly benign, can become ammunition for legal disputes. ${ }^{8,9}$

One of the most well documented cases of using innocuous debate in the scientific community as the basis for rejecting a scientific consensus was the fight against tobacco in both the court of public opinion and court of law. Science does not provide guarantees, and when it comes to toxins like those found in cigarettes, it measures the toxin exhaustively and sets levels of allowable intake. This intake level is not a sufficient condition to guarantee the absence of adverse health outcomes, but rather a buffer that ensures the levels that cause acute or chronic toxicity are generally not present. ${ }^{6}$ A lack of full guarantee was harnessed by the tobacco industry to sow doubt about the extent of health risks regarding its products. ${ }^{8}$ Testifying before the United States Congress during the "high-tide of anti-smoking sentiment," tobacco executives stated that cigarettes may have adverse effects, but the facts are not conclusive." 10 The scientific community saw the qualified conclusion more as a "benign contestation" rather than a deep foundational dispute regarding the malignance of tobacco. ${ }^{7}$

Attorneys play in these gray areas created by scientists, questioning expert witnesses' dedication to their conclusions. To defend science, the scientist must be ready to explain the difference between deep divides in the scientific community and mere quibbles over minor aspects of the issue at hand. ${ }^{8}$ As expert witnesses become more commonplace in the courts, the issue of expert witnesses themselves has been brought before the United States Supreme Court on multiple occasions. For nearly 70 years, Frye $v$. United States was the prevailing law. ${ }^{11}$ Under Frye, scientific testimony simply had to be generally accepted. A community of socalled scientists could coalesce and pass off questionable science as "generally accepted." Realizing some flaws in this standard, the court strengthened it in Daubert v. Merrell Dow Pharmaceuticals in 1994.12 This ruling created a focus on the reliability of results obtained. The courts now ask how the results were obtained, and whether said results are reliable and replicable according to the particular field. Daubert also ushered in Daubert Challenges, in which one side can challenge an expert witness and how they arrived at their conclusions. The Supreme Court gave examples of admissibility criteria, such as peer review, general acceptance of procedures utilized, rate of error, and replication of results. This also established the judge as the gatekeeper of admissible expert testimony in trial courts. As it so often does, the Supreme Court clarified the gate-keeping role of judges, as well as appropriate appellate review standards of expert testimony in General Electric Co. v. Joiner. ${ }^{13}$ Under Daubert as clarified by Joiner, judges are allowed to examine conclusions proffered by experts, in addition to experts' analysis of methods. These cases serve as guideposts to scientists and attorneys preparing to introduce scientific testimony in court. The testimony must call upon generally accepted scientific procedures, reliably attained through discipline-specific procedures. Furthermore, the scientific community must support the means used to derive conclusions utilized in expert testimony. These results must then be framed in an understandable manner for the judge, who has the final say regarding the ultimate admissibility of any proffered testimony. These rules were eventually consolidated into Federal Rule 702, which explicitly states what the courts said about expert testimony. The expert must be qualified to offer opinion, the opinion must be relevant to the issue in dispute, the methods used to find facts are reliable, and those methods were applied correctly to the derivation of fact. This rule has rendered the criteria in Daubert generally moot, but courts have still retained their discretion in what evidence is allowed in trial. ${ }^{14,15}$

Clearly, judges play a substantial role in the quality of evidence used in trial. This role is a weighty burden because their decisions may be used in future cases. Therefore, the gatekeeper role is absolutely essential in preventing inaccurate information from entering the courtroom and remaining there to harm innocent people in future cases. Trial attorneys are key allies to the propagation of good science in the courtroom, as they are responsible for the caliber of evidence introduced at trial.

The summation of the history of expert testimony in the courtroom is intended to help scientists understand legal challenges their work might face, so that they can be prepared to defend it when called upon. In describing the function of expert witnesses, the easiest path forward may seem to be for attorneys to simply fill in the gaps of understanding for judges and juries in technical debates. The notion that science will be accepted by lay people upon explanation is referred to as the deficit model of thinking. The deficit model of thinking has been roundly rejected by those who study the science of communication. ${ }^{7}$ Simply telling a judge or jury that certain facts exist and are pertinent is not sufficient to produce a favorable outcome for reliable science. All those who make up the cast of a court room trial bring pre-existing notions of science with them. Not all notions are favorable to science. In fact, several modern challenges afflict lay understanding of science. Due to the chaotic manner in which the scientific process proceeds, finding an absolute truth that all jurisprudential actors agree on may not be possible. ${ }^{9}$ Justification for this difficulty is now provided. 
An overarching issue of scientific perception is the plague of misinformation ravaging online communities. This problem could be a consequence stemming from the loss of the Fairness Doctrine. ${ }^{16}$ In the early days of radio, commentators were required to provide equal airtime to various ideologies. Requiring a left-leaning talk show to give time to their counterparts on the right, and vice versa may seem ludicrous. However, the Fairness Doctrine was temporarily upheld in the United States Supreme Court in a unanimous 1969 decision on grounds that the amount of "speech" on the radio was capped. The court reasoned that if one perspective dominated the finite radio waves, the American people would be deprived of a popular viewpoint, or alternate viewpoints in general. ${ }^{17}$ With the advent of the internet, the limits constraining the amount of available speech melted away, and in 2011 the Fairness Doctrine was officially repealed. ${ }^{18}$ Now that political commentators and news broadcasters have no need to consider opposing viewpoints, partisan strongholds have since quickly developed.

The internet was one of the driving factors behind increasing the amount of available "speech." The internet does not face the same restrictions as the radio and contains billions of pages. Additionally, the average user's access to these pages is ever changing based on the search engines they are using. ${ }^{19}$ The available viewpoints are legion, and this disharmonious choir of opinions can be quite disorienting, contrary to the belief that more information is better. ${ }^{1}$

A microcosm of the online landscape is Facebook. Nearly half of the world trusts Facebook as a source for news. ${ }^{20}$ This dependence makes the social media platform ripe for abuse and helps accelerate the breakdown of credible information sharing. The massive Cambridge Analytica Scandal that rocked millions of Facebook users exposed this vulnerability. ${ }^{21}$ The big-data company Cambridge Analytica sold the political preferences of Facebook users to political machines, who used the data to target users based on their political beliefs. The confirmation bias was leveraged to feed users information that matched their beliefs. ${ }^{16,22}$ The confirmation bias is the need to accept narratives that match personal ideologies, and is a built-in part of human neurobiology. ${ }^{23}$ This bias helps actors to rationalize their behaviors against facts or information that may not match their beliefs. ${ }^{24}$ Social media catered to the predictable human psychology of constructing of echo chambers made up of people who agree with each other. These biases were exploited by algorithms that pushed consumers of social media toward information that fit their existing beliefs, with no guarantee of the veracity of that information.

This path to misinformation created unfortunate consequences for scientists striving to educate the public on their work. Science is a never-ending process and sometimes examines issues that the public may wish to not have examined. ${ }^{1}$ When partisans are confronted with scientific information that does not align with their beliefs, the initial belief is thought to be strengthened even in the face of contradicting information. ${ }^{22}$ This phenomenon has become painfully apparent with the advent of the novel coronavirus, (Sars-CoV-2, or COVID-19). Contemporary Facebook newsfeeds are filled with politicized memes advocating for and against the wearing of facemasks. The Center of Disease Control issued initial guidance that facemasks be worn only by those with a confirmed diagnosis of COVID-19.25 As the scope of the disease grew, the CDC released new guidance that all people should wear facemasks in public. ${ }^{25}, 26$ Editorials and social media posts criticizing these actions are legion, another example depicting the complex relationship of science with the public.

These findings have caused some in the scientific community to question whether effective scientific communication is possible in a society mired in scientifically inaccurate information. ${ }^{15}$ Misinformation became so infamous that the World Economic Forum declared misinformation a crisis on par with terrorism..$^{20}$ Misinformation, and the vastness of available data complicate the dissemination of scientific knowledge, and threaten to block a working understanding of science that will empower judicial fact finders. 1 , 16, 20, 22

Another issue that contributes to the misinformation crisis is the overrepresentation of scientific fraud. The vast majority of scientists conduct their research in good faith, working to find solutions to problems. Society is better because of their efforts. However, a small number of unscrupulous actors pursue scientific knowledge without these benign intents. ${ }^{27},{ }^{28}$ Scientists have been accused of providing evidence that ostensibly clears products or advances in medicine for mass distribution but are ultimately false positives. One example is cancer research. Society has long sought a silver bullet to use against this dreaded disease. Some scientists were eager to oblige society's yearnings, and spuriously claimed they had found this silver bullet. When these fraudulent claims were exposed, scientists retreated disgraced from their claims and the 24-hour news cycle used their lack of scruples as evidence that science as a whole is failing. ${ }^{16,27}$ News agencies correctly function as watchdog entities, and the reader need not suppose that these channels abuse their power by shining the detecting light of public scrutiny on those who behave with impropriety. The issue lies with the availability heuristic of those who consume news. The availability heuristic is a psychological phenomenon that explains certain aspects of decision making. When people form opinions of local crime, or prevalence of small airplane crashes, the amount of information available to the person predicts their mental representation of the frequency and severity of these events. ${ }^{29}$ These representations are typically biased and inaccurate. When consumers frequently see stories of scientific impropriety, these biases become active and consumers begin to believe that impropriety is the norm in the scientific process. ${ }^{16}$ 
Germane to fraud is the alleged replication crisis plaguing many different scientific disciplines. Critics allege science is at a standstill due to the rise in failed replication of original, promising research. Indeed, retractions of initially published research are rising. ${ }^{27}$ This evidence led to claims of science being broken, which seriously threatens the legitimacy of findings and science generally. The public began to wonder whether any scientific advances can be trusted, or if scientists in white lab coats will retract research when another scientist attempts to replicate their findings and fails. This concern, similar to the fraud concerns, is not being contextualized appropriately. In a study of scientific articles published from January 2000 to December 2015 by the peerreviewed journal BioMed Central, the authors found that 134 studies had been retracted. ${ }^{30}$ From an outsider's perspective, 134 studies seems to be an alarming amount of research that had initially passed the muster of peer reviewers, to ultimately be pulled from publication. Upon further inspection, this number makes up $0.07 \%$ of all published articles from BioMed Central. Invisible to the public are the volumes of studies that proceed with propriety. Additionally, nearly half of these retractions came from the authors themselves. ${ }^{30}$ Science is a self-policing industry, and internal criticism affecting change in the scientific community demonstrates the scientific process is alive and healthy. Thus, the issue is not fraud or challenges arising from replication questions, but the public perception of these challenges.

Despite the positive prognosis of science resulting from correct framing of the fraud and replication issues, the problem is being presented to the media as an indication that science is dying. The alleged crisis of confidence is exacerbated by some in the communication industry who use alarmist language when describing concerns surrounding replication. For instance, science reporter Richard Harris wrote in the New York Times about all the ills of science in an article entitled "Rigor Mortis: How Sloppy Science Creates Worthless Cures, Crushes Hope, and Wastes Billions.” In the world of superficial scholarship, this headline is a spark that ignites a bonfire of backlash. However, when asked further about this "Rigor Mortis," Harris confesses that acknowledging that some studies are flawed is actually a positive step in the right direction. ${ }^{31}$

The challenges of misinformation, fraud, and replication threaten the ability to advance science, as well as its legitimacy in the court room. For scientists who do venture into the courtroom, the threat exists of some unfortunate consequences, such as loss of credibility or stigmatization. ${ }^{32}$ These consequences may occur even if the scientist or expert is participating in good faith. Despite these risks, venturing into the courtroom is a pressing need for the long-term viability of science. As noted throughout this paper, science provides real value to society, and scientists themselves are best prepared to share and defend its results. ${ }^{6,33}$ However, defending science cannot be left to scientists themselves. Attorneys and judges must take an active role in endorsing sound science because simply informing juries is not adequate. ${ }^{7}$

\section{Part II: Sharing Knowledge in the Courtroom}

Finding common foundational truth is a difficult endeavor. Some believe that science is created with firm rules and produces absolute truths that should guide society's every step. Conversely, others see scientific participation as open to all, and the results open to more liberal intrepretation. ${ }^{34}$ These differences in the perception of science led scholars to explore the underpinnings of knowledge, and how societies manufacture knowledge. ${ }^{9}, 33$ This is the sociology of scientific knowledge (SSK). Jasanoff has made invaluable contributions to this field, some of which are cited in this paper.9, 34 The literature on how knowledge is derived constitutes a valuable part of the science and law discussion. Each piece of scientific knowledge, or fact, exists inside societal contexts. The courts play a valuable role in deconstructing scientific processes to better understand how they fit inside these contexts. ${ }^{9,}, 34$

Social institutions largely govern the formation of these contexts. ${ }^{34}$ These contexts are not consciously noticed until they are deconstructed. Deconstruction takes place when scientists begin to examine why they research the subjects they research. Scientists often state their conclusions only follow from observable facts, but these facts and conclusions are usually products of the contexts they originate from. For example, agricultural scientists investigating the production of different crop varieties conclude that some varieties yield better than others. The observation is ostensibly "true," but crop scientists are asking these questions because the institutions around food production prioritize increased yields. These institutions are made of consumers clamoring for better food at lower prices, and corporations striving to meet those needs. Therefore, the "fact" that one variety yields better than another originates from the goal to satisfy market demands. One could also observe that some crop varieties have different colors or sizes, but they are typically not relevant and therefore not included as facts despite other observations of qualities that are also "true."

As science has become more sophisticated, institutions have looked to add science to criminal law, promising greater accuracy in delivering justice. Societies generally desire to punish lawbreakers, especially in the case of violent crimes. The masses desire to feel safe, and there may be pressure to find facts that incarcerate alleged lawbreakers. Several disciplines lacking rigor, and while well-meaning, have used these incentives to enter the courtroom and gain significance and even prestige. Among these dubious practices is bite mark analysis. 
Bite mark analysis deserves extensive review because the damage it has done to the basic tenets of a fair criminal justice system. The Sentencing Project is a non-profit institution that examines issues surrounding incarceration in the United States. In a 2018 report to the United Nations, this organization examined incarceration in the United States and found that people of color interact with police more often, are incarcerated at higher rates, and serve longer. ${ }^{35}$ These outcomes are due in part to the inclusion of science that in many cases does not meet the appropriate standards of review established by the US Supreme Court. Removing bad science from the court room may increase equity in sentencing. Relying materially on poorly constructed science to place someone in prison should not occur in a society that claims due process rights for all, as promised in the fourteenth amendment to the US Constitution. ${ }^{36}$

Howard $v$. State illustrates all aspects of this issue perfectly. Eddie Lee Howard was convicted using bitemark evidence from the infamous "forensic odontologist," or bite mark expert Dr. Michael West, who achieved prominence from his bite mark testimonies in several high-profile cases involving violent crime. ${ }^{39}$ Howard was originally convicted for a crime that occurred in 1992, the murder and apparent rape of an 84-year-old woman in her own home. The crime was heinous; justice needed to be served. Dr. West provided the only incriminating evidence against Howard: bite mark analysis on the bite marks left by the perpetrator on the victim. ${ }^{38}$ Howard struggled to appeal his case through the system, claiming that bad science of forensic odontology had been used to convict him. After years of procedural slog, his appeals were denied in 2006. As written earlier, the judges who handed this decision down relied on previous judicial opinions to support their decision, including Brooks $v$. State. ${ }^{39}$ The Brooks case also relied on bite mark evidence to convict the alleged perpetrator, Levon Brooks. Brooks would be exonerated in 2007 by DNA evidence. ${ }^{38}$ The appellate court also used Daubert to insist that the responsibility of admitting evidence lay solely at the door of trial courts. Instead of helping rid the court of bad science, Daubert allowed the bite mark evidence to continue. After winding through decades of legal procedure, Howard remains on death row with his case before the Mississippi Supreme Court. ${ }^{40}$

As more scientists turned the eye of scrutiny on dental odontology, several issues were raised with the practice. No acceptable error rate existed, meaning bite marks of two different people could be confused. The scientific community, as described previously in this paper, did its job and ousted Dr. West from its ranks. ${ }^{41}$ Sadly, the damage done to Levon Brooks and Eddie Lee Howard cannot be reversed. The deconstruction included in the SSK could have prevented such controversial evidence from finding its way into American courts. The cynical critic might counter that bite mark analysis is the exact reason why science should be devalued or even excluded from courts. However, abandoning science would be foolhardy. Science can still provide answers and has an efficacious process of peer review to guard against fraud and misinformation.

Howard is a cautionary tale. Courtrooms are detailed places that require exactness, and the attorney is a key ally in preparation. The most effective scientists enter the scrum of the courtroom only after adequate preparation from attorneys. ${ }^{42}$ They can advise scientists how to effectively frame and contextualize their knowledge so that juries and judges will fully benefit from the testimony. The American Bar Association has many resources on proper preparation and should be consulted for best results. This point cannot be overstated because of the disproportionate value lay juries, and sometimes judges, place on scientific evidence. ${ }^{4}$ Because the mood of the audience is paramount to how a message is understood, proper presentation is vital to the success of expert testimony. ${ }^{43}$ The best expert testimony uses the role of a teacher for the expert witness, that meets judges and juries where they are and helps them understand complex issues in a simple way.6, 7, 41, 44 Teaching can help, but recalling the deficit model of thinking, scientists cannot stop at education. Deconstruction of issues can help unravel the biases lay fact finders bring with them into the courts. When deposing an expert witness, an attorney might walk the scientist through the basis for why they do their research, and why it is important to their discipline.

\section{Conclusion}

Science plays an invaluable role in society but is consigned to a relationship with man-made laws and systems. Science faces many challenges that threaten to impede its forward progress, such as fraud and replication concerns. The SSK and the deficit model of thinking inform scientists that the better way to share science is by deconstructing scientific phenomena and providing context. The courtroom is the crucial space for advocating on behalf of sound science.

Society stands in need of scientific communication. Achieving this goal requires scientists and legal professionals to work in concert with each other. In an increasingly partisan environment, speaking in terms of scientific fact has never been more important. ${ }^{16}$ Scientists' time and resources are continually limited, but communication should be an essential component of their effort due to the far-reaching impact of that communication. Furthermore, the plague of misinformation threatens to engulf society. If the public cannot see correct and reliable science germane to their lives, scientific progress may never achieve its lofty goals of bettering society, and science itself may lose its legitimacy. ${ }^{6,33,44}$ This would be a tragedy because scientific research can offer much in terms of healthcare, food production, and infrastructure. From the perspective of attorneys, their knowledge is vast regarding the nuances of legal procedure, but they can benefit from hearing the informed opinions of scientific professionals. This specialized knowledge can aid lawyers as they formulate their arguments and case strategy. Respectable, honest scientists are 
irreplaceable, and their communication has never been in greater demand than in these times of misinformation. However, these scientists can only succeed in their efforts with the help of legal professionals who are competent in correctly framing robust scientific results.

\section{ACKNOWLEDGEMENTS}

Dr. Eric Kirby Esq. supported me throughout the process of authoring this paper. Dr. Richard O. Parker and Dr. Jeff Miller gave insightful feedback as well. Jayci Hacker advised the writing of this paper from start to finish. Although Evan Miller is the only author, he could not have completed this paper without these individuals' help.

\section{REFERENCES}

1. Kropp, C. and Wagner, J. (2010) Knowledge on stage: Scientific policy advice, Science, Technology, \& Human Values, 35(6), 812838. https:/ / doi.org/10.1177/0162243909357912

2. USCS Federal Rules of Evidence 602. (2011).

3. USCS Federal Rules of Evidence 703. (2011).

4. Kaplan, A. B., and Puracal, J. C. (2017) It's not a match: Why the law can't let go of junk science, Albany Law Review, 81(3), 895-939.

5. Ellman, I. M., and Ellman, T. (2015) Frightening and high: The supreme court's crucial mistake about sex crime statistics. Constitutional Commentary, 30, 495-508. https:/ / scholarship.law.umn.edu/cgi/viewcontent.cgi?article=1429 docontext=concomm

6. Wilson, R. (2004) Ensuring sound science in the courts. Pergamon Press: An Imprint of Elsevier Science. 26. bttps://doi.org/10.1016/j.techsoc.2004.01.028

7. Simis, M. J., Madden, H., Cacciatore, M. A., and Yeo, S. K. (2016) The lure of rationality: Why does the deficit model of thinking persist in science communication? Public Understanding of Science, 25(4), 400-414. bttps://doi.org/10.1177/0963662516629749

8. Shwed, U. and Bearman, P. S. (2010), The temporal structure of scientific consensus formation. American Sociological Review, 75(6), 817-840. http:// doi.org/10.1177/0003122410388488

9. Jasanoff, S. (1992) What judges should know about the sociology of science. Jurimetrics, 32(3), 345-359. bttps:// doi.org/10.1177/1075547098019004003

10. Hilts, P. J. (1994) Tobacco chiefs say cigarettes aren't addictive. The New York Times, https:/ / wmw.nytimes.com/1994/04/15/ us/tobacco-chiefs-say-cigarettes-aren-t-addictive.html (accessed Nov 2019)

11. Frye v. United States, 293 F. 1013. (D.C. Cir. 1923).

12. Daubert v. Merrell Dow Pharmaceuticals, 43 F.3d 1311. (9th Cir. 1995).

13. GE $v$. Joiner, 522 U.S. 136 (1997).

14. Fed. R. Evid. 702.

15. Phillips v. C.R. Bard Inc., 2014 U.S. Dist. Lexis 174506. (2014).

16. Massey, D. S., and Iyengar, S. (2018) Scientific communication in a post-truth society. PNAS, 116(16), 7656-7661. https://doi.org/ 10.1073/pnas.1805868115

17. Red Lion Broadcasting Co. v. FCC, 395 U.S. 367. (1969)

18. Stefon, M. (2017) Fairness doctrine. Encyclopedia Britannica, https:// www.britannica.com/topic/Fairness-Doctrine (accessed Sept 2019)

19. Van den Bosch, A., Bogers, T., and de Kunder, M. (2016) Estimating search engine index size variability: a 9-year longitudinal study. Scientometrics, 106(2), 839-856. http:/ / doi.org/10.1007/s11192-016-1863-r.

20. Reuters Institute, Digital News Report. https:// reutersinstitute.politics.ox.ac.uk/sites/default/files/201906/DNR_2019_FINAL_0.pdf(accessed Oct 2019)

21. Rosenblatt, J. (2019) Facebook faces massive damages in cambridge analytica suit. Bloomberg.Com, http:/ / search.ebscohost.com.proxy.li.suu.edu:2048/login.aspx?direct=true $* d b=b u b \nLeftarrow A N=138525898$ \& site=ehost-live (accessed Oct 2019)

22. Peruzzi, A., Zollo, F., Schmidt, A. L., and Quattrociocchi, W. (2018) From confirmation bias to echo-chambers: A data-driven approach. Sociologia e Politiche Sociali, 21(3), 47-74. https:/ / doi.org/10.3280/SP2019-003004

23. Kaplan, J.T., Gimbel, S. I., and Harris, S. (2016) Neural correlates of maintaining one's political beliefs in the face of counterevidence. Science Reports, 6, 39589. http:/ / doi.org/10.1038/srep39589

24. Scott, E., Kallis, G., and Zografos, C. (2019) Why environmentalists eat meat. PLoS ONE, 14(7), 1-9. https:// doiorg.proxy.li.suu.edu:2443/10.1371/journal.pone.0219607

25. Marfin, C. (2020) Why did the recommendation on wearing masks change? Curious texas investigates. The Dallas Morning News. https:// www.dallasnews.com/news/public-health/2020/04/08/why-did-the-recommendation-on-wearing-face-masks-change/(accessed Aug 2020)

26. Centers for Disease Control, CDC calls on americans to wear masks to prevent COVID-19 spread, (2020) https:/ / www.cdc.gov/ media/ releases/2020/p0714-americans-to-wear-masks.html (accessed Aug 2020) 
27. Jamieson, K. H. (2018) Crisis or self-correction: Rethinking media narratives about the well-being of science. $P N A S$, 115(11), 2620-2627. https:// doi.org/10.1073/pnas.1708276114

28. Union of Concerned Scientists, Heads they win, tails we lose, https://www.ucsusa.org/sites/default/files/2019-09/heads-they-winreport.pdf (accessed Oct 2019)

29. Tversky, A., and Kahneman, D. (1974) Judgment under uncertainty: Heuristics and biases. Science, 185(4157), $1124-1131$. bttp:/ / doi.org/ 10.1126/ science.185.4157.1124

30. Moylan, E. C., and Kowalczuk, M. K. (2016) Why articles are retracted: A retrospective cross-sectional study of retraction notices at BioMed Central. BMJ Open. https:// doi.org/10.1136/bmjopen-2016-012047

31. Oransky, I. (2017) Failure is an essential part of science: A Q\&A with the author of a new book on reproducibility. Retraction Watch. retractionwatch.com/2017/04/04/failure-essential-part-science-qa-author-new-book-reproducibility/(accessed Dec 2019)

32. Newman, P (2000) Law and science: The testing of justice, New York University Annual Survey of American Law, 57, 419.

33. Besley, J. C., Dudo, A., and Storksdieck, M. (2015) Scientists' views about communication training. Journal of Research in Science Teaching, 52(2):199-220. https:// doi.org/10.1002/tea.21186

34. Jasanoff, S. (2003) Breaking the waves in science studies: Comment on h.m. collins and robert evans, the third wave of science studies. Social Studies of Science, 33(3), 389-400. https:/ / doi.org/10.1080/19460171.2010.490642

35. The Sentencing Project, Report to the United Nations on Racial Disparities in the US Criminal Justice System bttps:/ / www.sentencingproject.org/publications/un-report-on-racial-disparities/(accessed Aug 2020)

36. U.S. Const. Amend. XIV.

37. Howard v. State, 945 So. 2d 326. (Miss. 2006).

38. Fabricant, C. and Carrington, T. (2016) The shifted paradigm: Forensic science's overdue evolution from magic to law. 4 Va J. Crim L. 1.

39. Brooks v. State, Miss. Lexis 318. (1999).

40. Seasly, J. (2019) Eddie lee howard jr.: Remains on death row based on dubious "bite mark" testimony. News, Unrequited Innocence. Injustice Watch, https:// wmw.injusticewatch.org/projects/ unrequited-innocence/2019/eddie-lee-howard-jr-mississippi/(accessed Aug 2020)

41. Balko, R. (2016) Expert witness goes nuts during questioning for mississippi death penalty case. The Washington Post, bttps:/ / www.washingtonpost.com/ news/the-watch/wp/2016/08/24/expert-witness-goes-nuts-during-questioning-for-mississippi-death-penaltycase/(accessed Aug 2020)

42. Harlan, E. R., and Coulson, J. M. (2019) Tips from the bench on the presentation of expert witnesses at trial. Practice Points, American Bar Association, https:// www.americanbar.org/groups/litigation/committees/expert-witnesses/practice/2019/tips-from-the-bench-onthe-presentation-of-expert-witnesses-at-trial/ (accessed Nov 2019)

43. Whiting, A., Kecinski, M., Tongzhe, L., Messer, K. D., and Parker, J. (2019) The importance of selecting the right messenger: A framed field experiment on recycled water products. Ecological Economics, 161, 1-8.

https:// doi.org/ 10.1016/j.ecolecon.2019.03.004

44. Besley, J. C., Dudo, A. D., Yuan, S., and Ghannam, N. A. (2016) Qualitative interviews with science communication trainers about communication objectives and goals. Science Communication, 38(3), 356-381. bttps:// doi.org/10.1177/1075547016645640

\section{ABOUT STUDENT AUTHORS}

At the time of writing, Evan Miller is pursuing a Juris Doctor at the University of Missouri School of Law. He completed a Bachelor of Arts in Psychology at Southern Utah University.

\section{PRESS SUMMARY}

Science and law need each other, but problems occur when science is used in law. The common law focus in American court systems can be problematic. These problems have not always produced the best outcomes for those on trial. By harnessing the sociology of scientific knowledge, these shortcomings can be addressed, and science and law can work together in achieving equitable justice and pushing society forward instead of pulling it backwards. 